\title{
PENGARUH KNOWLEDGE MANAGEMENT TERHADAP KINERJA KARYAWAN
}

\author{
Fransiska Ekobelawati \\ Akademi Sekretari Manajemen Indonesia Pontianak (ASMI) \\ Email : $\underline{\text { Sischasira06@Gmail.com }}$
}

\begin{abstract}
ABSTRACK
This research aims to know the influence of Knowledge Management onemployee performance on PT. Anzon Toyota Pontianak and to find out where Knowledge Management indicators that are most influential on employee performance. This research uses the IBM SPSS statistics application. The population in this research are the employee of PT. Anzon Toyota Pontianak. The sample used 40 respondents with using the saturated sample. Technique of data analysis in this research used simple linear regression analysis

Results of the study show that there is influence between variable Knowledge Management which consists of three indicators, namely Personal Knowledge, Job Procedure, and technology on employee performance with determinant of coefficients is 0.256. Data analysis showed that the Personal Knowledge is the indicators with the most biggest influence compared to other indicators.
\end{abstract}

Keywords: Knowledge Managemesnt, Employee Performance.

\section{PENDAHULUAN}

Dunia bisnis moderen saat ini telah memasuki era yang disebut postindustrial age atau information age (Tillman, 2008). Era yang ditandai dengan perubahan paradigma dari pekerjaan yang hanya mengandalkan fisik semata sebagai basis kerja menjadi pekerjaan yang berbasiskan pengetahuan (knowledge work). Informasi menjadi sebuah kata kunci penting di era ini. Kumpulan informasi yang tersistemasi dengan baik kemudian akan membentuk sebuah pengetahuan. Pengetahuan inilah yang pada akhirnya menjadi basis penting di dalam jantung bisnis moderen saat ini.

Pengetahuan yang dimiliki oleh suatuorganisasi merupakan asset yang sangat berharga (Lopez dkk, 2011) dan merupakan aset yang tak kasat mata atau intangible asset (Goel dkk, 2010), pengetahuan juga merupakan sumberdaya internal perusahaan yang paling bernilai, unik, sulit digantikan, dan sulit ditiru (Kaplan dkk, 2001). Dengan pengetahuan dan kemampuan untuk menciptakan pengetahuan baru, perusahaan dapat menggunakan, memanipulasi, dan mentransformasikan sumberdaya lain. Organisasi harus menyadari pentingnya mengelola dan memanfaatkan sebaik-baiknya pengetahuan dari individu-individu yang ada dalam organisasi tersebut sebagai aset organisasi.

Permasalahan mengenai kinerja merupakan permasalahan yang akan selalu dihadapi oleh pihak manajemen perusahaan, karena itu manajemen perlu mengetahui faktor-faktor yang mempengaruhi kinerja karyawan. Faktor-faktor yang dapat mempengaruhi kinerja karyawan tersebut akan membuat manajemen perusahaan dapat mengambil berbagai kebijakan yang diperlukan, sehingga dapat meningkatkan kinerja karyawannya agar sesuai dengan harapan perusahaan (Habibah, 2001).

Ravianto (1988) menyebutkan faktor-faktor yang mempengaruhi kinerjakaryawan diantaranya yaitu pendidikan dan latihan, disiplin, sikap dan aktivitas kerja, motivasi, masa kerja, gizi dan kesehatan, tingkat penghasilan, jaminansosial, lingkungan kerja, teknologi dan sarana produksi, kesempatan kerja, serta kebutuhan untuk berprestasi. Faktor-faktor tersebut berpengaruh terhadap karyawan dalam melaksanakan tugas-tugas yang diberikan kepadanya, sehingga hasil akhirnya adalah kinerja karyawan itu sendiri, apakah akan semakin baik atau semakin buruk.

Groff \& Jones (2003:2) mengatakan knowledge management is taken as tools, techniques and strategies to retain, analize, organize, improve and share business expertise. Manajemen pengetahuan adalah alat, teknik, strategi untukmenyimpan, menganalisis, mengorganisir, meningkatkan dan membagikanpengalaman bisnis. Menurut Wigg dalam Liebowitz (1999:6), knowladge management is the systematic, explicit and deliberate building, renewal and 
application of knowledge to maximize an enterprise $s$ knowledge- related effectiveness and return from its knowledge assets.

Manajemen

pengetahuanadalah pembangunan yang sistematis, lamban, pembaharuan dan penerapanpengetahuan untuk memaksimalkan efektivitas pengetahuan perusahaan dankeuntungan aset pengetahuan. Hibbard dalam Halawi et al (1997), knowladge management is process of capturing a company $s$ collective expertise wherever it resides in data base, on paper, or in people s head and distributing it to where ever it can help produce the biggest payoff.

Kinerja SDM merupakan istilah yang berasal dari kata job performance atau actual performance (prestasi kerja atau prestasi sesungguhnya yang dicapaiseseorang). Definisi kinerja menurut Kusriyanto (1991) dalam Mangkunegara(2005) adalah perbandingan hasil yang dicapai dengan peran serta tenaga kerjapersatuan waktu (lazimnya per jam). Gomes (1995) dalam Mangkunegara (2005)mengemukakan definisi kinerja karyawan sebagai ungkapan seperti output,efisiensi serta efektivitas sering dihubungkan dengan produktivitas. Selanjutnyadefinisi kinerja karyawan menurut Mangkunegara (2005) adalah hasil kerja secarakualitas dan kuantitas yang dicapai oleh seseorang karyawan dalam melaksanakantugasnya sesuai dengan tanggung jawab yang diberikan kepadanya.

Oleh karena itu disimpulkan bahwa kinerja SDM adalah prestasi kerja atau hasil kerja (output) baik kualitas maupun kuantitas yang dicapai SDM persatuan periode waktu dalam melaksanakan tugas kerjanya sesuai dengan tanggung jawab yang diberikan kepadanya.

\section{METODE PENELITIAN}

\section{Bentuk Penelitian}

Metode dalam penelitian ini bersifat penejelasan yang bertujuan untuk memberikan gambaran dan penjelasana secara sistematis mengenai fenomena tertentu melalui pengujian hipotesis, yaitu mengenai Pengaruh Knowledge Management Terhadap Kinerja Karyawan.

\section{Populasi dan sampel}

Objek penelitian sekaligus populasi yang menjadi responden penelitian ini adalah karyawan PT Anzon Pontianak. Metode yang digunakan dalam pengambilan contoh adalah metode sensus, atau total sampling. Sensus adalah proses investigasi dengan mengamati semua penelitian.
Jumlah karyawan yang dijadikan responden adalah 40 orang.

\section{Analisis Data}

Dalam upaya menjawab permasalahan dalam penelitian ini maka digunakan analisis regresi linear sederhana. Analisis regresi pada dasarnya adalah studi mengenai ketergantungan variabel dependen (terikat) dengan satu atau lebih variabel independen (variabel penjelas/bebas), dengan tujuan untuk mengestimasi dan/atau memprediksi rata-rata populasi atau nilai-nilai variabel dependen berdasarkan nilai variabel independen yang diketahui (Ghozali, 2005).

Untuk regresi yang variabel independennya terdiri atas dua atau lebih, regresinya disebut juga regresi berganda. Oleh karena variabel independen diatas hanya mempunyai satu variabel, maka regresi dalam penelitian ini disebut regresi sederhana. Analisis data menggunakan alat bantu aplikasi ststistik SPSS.

Penggunaan analisis deskriptif ini untuk mengungkap gambaran data empiris secara deskriptif dengan cara menginterpretasikan hasil pengolahan data melalui tabulasi frekuensi serta mengungkapkan kecenderungan data dilihat dari mean arau rata-rata. Hasil analisis deskriptif berguna untuk mendukung interpretasi terhadap hasil analisis dengan analisis regresi (Umar, 2005).

\section{Pengujian Hipotesis}

Uji t dilakukan untuk menguji pengaruh variabelvariabel bebas secara parsial terhadap variabel terikat (Gujurat,1998:126). Hasil yang diperoleh dibandingkan dengan ttabel dan tingkat signifikansi $(\alpha=0.05)$. Bila nilai signifikansi $<\alpha=0.05$ berarti variabel bebas (Knowledge Management) mempunyai pengaruh secara parsial terhadap variabel tak bebas (Kinerja Karyawan) dan bila nilai signifikansi $>\alpha=0.05$ berarti variabel bebas tidak mempunyai pengaruh secara parsial terhadap variabel dependent.

\section{HASIL DAN PEMBAHASAN HASIL}

Uji validitas dengan menggunakan motode analisis korelasi Product Moment Pearson pada tingkat kepercayaan (significance level) sebesar $\alpha=$ 0,05 , dengankriteria jika nilai $\mathrm{r}$ yang diperoleh sebesar $\geq 0,3$. Maka instrument yang diujicobakandinyatakan valid.

Uji reliabilitas bermaksud untuk mengetahui adanya konsistensi alat ukur dalam penggunaannya atau dengan kata lain alat ukur tersebut mempunyai 
hasil yang konsisten apabila digunakan berkali-kali pada waktu yang berbeda. Untuk uji reliabilitas ini digunakan teknik Alpha Cronbach, dimana Suatu instrument dikatakan reliable jika nilai alpha cronbach sebesar $\geq 0,6$.

Dasar pengambilan keputusan dalam uji normalitas yakni : jika nilai signifikansi lebih besar dari 0,05 maka data tersebut berdistribusi normal. Sebaliknya, jika nilai signifikansi lebih dari 0,05 maka data tersebut tidak berdistribusi normal. Berdasarkan output di atas, diketahui bahwa nilai signifikansi (Asymp. Sig. (2-tailed) sebesar 0,933 lebih besar dari 0,05, sehingga dapat disimpulkan bahwa data yang diuji berdistribusi normal.

Pengujian dan pembuktian secara empiris pengaruh antar variabel penelitian ini selain menggunakan statistika deskriptif juga digunakan analisis statistika yaitu analisis regresi linear sederhana untuk melakukan pengujian terhadap hipotesis yang diajukan dalam penelitian ini. Dari pengujian tadi akan dapat ditarik kesimpulan berdasarkan penaksiran. Hasil analisis regresi linear sederhana yang menguji pengaruh variabel Knowledge Management (X1) terhadap Kinerja Karyawan (Y) studi PT Anzon Pontianak.

Hasil analisis koefisien Korelasi (R) menyatakan bahwa besarnya koefisisen korelasi (R) yang diperoleh sebesar 0,506. Hasil tersebut jika disesuaikan dengan tafsiran koefisisen korelasi dalam Sugiyono (2003 : 214) adalah cukup kuat, yang berarti bahwa variabel Knowledge Management mempunyai hubungan terhadap Kinerja karyawan.

Hasil analisis koefisien determinasi (R2) menyatakan bahwa besarnya koefisien determinasi adalah sebesar 0,256. Ini berarti bahwa Kinerja karyawan ditentukan ataupun dipengaruhi Knowledge Management sebesar 25,6\%. Selebihnya dipengaruhi oleh faktor diluar penelitian ini sebesar $74,4 \%$ seperti variabel motivasi, kompensasi, lingkungan kerja, komitmen dan beberapa variabel lainnya.

Berdasarkan hasil uji analisis diketahui bahwa nilai signifikansi t untuk variabel Knowledge Management 0,001, lebih kecil daripada nilai level of significant $(\alpha)$ sebesar 0,05 . Dengan demikian hipotesis yang menyatakan ; Knowledge Management berpengaruh terhadap Kinerja karyawan PT Anzon Pontianak diterima. Ini menunjukkan bahwa Semakin baik Knowledge Management yang dimiliki seorang karyawan maka semakin baik pula kinerja yang akan mereka berikan bagi perusahaan.

\section{Pembahasan}

Dalam teori yang dipaparkan pada bab sebelumnya, pengalaman adalah salah bentuk Tacit Knowledge yang secara sederhana berarti pengetahuan yang tidak terlihat dan berada dalam diri seseorang.

Dengan pengalaman yang dimiliki responden setuju bahwa pekerjaan yang mereka lakukan akan lebih mudah. Seperti yang kita ketahui bahwa responden pada penelitian ini berasal dari berbagai divisi dalam perusahaan yaitu divisi administrasi, pemasaran, dan perbengkelan.

Sehingga jika berbicara tentang pengalaman pada penelitian ini berarti pengalaman pekerjaan dibidang kerja masing-masing karyawan, seperti misalnya karyawan bidang administrasi berpengalaman melakukan penginputan dan pengiriman serta penyimpanan data-data perusahaan, karyawan dibidang marketing berpengalaman dalam memasarkan produknya berdasarkan data-data makro yang dimilikinya, mempunyai banyak relasi, mudah membangun hubungan, mempunyai strategi pemasaran yang tepat dan lain sebagainya yang diperlukan sebagai seorang marketer, dan yang terakhir pengalaman yang dimiliki seorang karyawan pada divisiperbengkelan yaitu mampu menyelesaikan pekerjaan lebih cepat dari pada yang lainnya.

Itulah mengapa, kualitas dan kuantitas kerja yang karyawan hasilkan sangat dipengaruhi oleh pegalaman yang dimiliki.Pernyataan ini didukung oleh hasilpenelitian yang dilakukan oleh (Smith,2001) bahwa Karyawan yang memiliki pengetahuan tacit dan eksplisit cenderung memiliki kepercayaan diri yang tinggi terhadap pekerjaan yang mereka lakukan karena mereka mempunyai pengalaman serta standart kerja yang harus mereka jalankan. sehingga dalam melakukan pekerjaannya mereka merasa lebih aman terhadap adanya kesalahan. (Smith,2001).

\section{Kesimpulan}

Penelitian ini dilatarbelakangi oleh fenomena dilapangan yang menunjukkan bahwa keberhasilan suatu perusahaan sangat tergantung terhadap kinerja karyawannya. Berdasarkan hasil analisis data, analisis deskriptif, pembuktian hipotesis dan pembahasan hasil maka dapat ditarik kesimpulan bahwa KnowledgeManagement berpengaruh terhadap kinerja karyawan sebesar 25,6\%, dengan indikator personal knowledge sebagai indikator 
mempunyai pengaruh terbesar dibandingkan Job Procedure dan Teknologi. Penelitian menyisahkan implikasi untuk penelitian selanjutnya untuk mengungkap variabel - variabel lain yang berpengaruh terhadap kinerja karyawan dimana pada penelitian ini variabel KnowledgeManagement hanya memberi pengaruh sebesar $25,6 \%$ yang artinya bahwa masih ada $74,4 \%$ variabel lain yang berpengaruh terhadap kinerja karyawan khususnya pada PT Anzon Pontianak.

\section{Daftar Pustaka}

Bernardo, J. M., \& Smith, A. F. (2001). Bayesian theory: IOP Publishing.

Geller, B., Tillman, R., Bolhofner, K., \& Zimerman, B. (2008). Child bipolar I disorder: prospective continuity with adult bipolar I disorder; characteristics of second and third episodes; predictors of 8-year outcome. Archives of general psychiatry, 65(10), 1125-1133.

Habibah, S. (2001). Meningkatkan Kinerja Melalui Mekanisme 360 Derajat. Telaah Bisnis, 2(1), 27-37.

Imam, G. (2005). Aplikasi analisis multivariate dengan program SPSS. Semarang: Badan Penerbit Universitas Diponegoro.

Kusriyanto, B. (1991). Manajemen Produktivitas Karyawan. Jakarta: Gramedia.

Liebowitz, J. (1999). Knowledge management handbook: CRC press.

Lopez-Candales, A. (2001). Metabolic syndrome X: a comprehensive review of the pathophysiology and recommended therapy. Journal of medicine, 32(5-6), 283300.

Mangkunegara, A. P., \& Prabu, A. (2005). Evaluasi kinerja sumber daya manusia. Bandung: Refika Aditama.

Meyer, J. B., Kaplan, D., \& Charum, J. (2001). Scientific nomadism and the new geopolitics of knowledge. International Social Science Journal, 53(168), 309-321.

Patel, N., Goff, L. K., Clark, T., Ford, A. M., Foot, N., Lillington, D., . . . Saha, V. (2003). Expression profile of wild-type ETV6 in childhood acute leukaemia. British journal of haematology, 122(1), 94-98.

Punjani, B. (1998). Plants used as tooth brush by tribes of district Sabarkantha (North Gujurat) Ethnobotany 10. 133-135: En.
Ravianto, J. (1988). Materi Pokok Dasar-Dasar Produktivitas. Jakarta. Penerbit Karunika Jakarta.

Roszak, T. E., Gomes, M. E., \& Kanner, A. D. (1995). Ecopsychology: Restoring the earth, healing the mind: Sierra Club Books.

Sherman, S., Blaut, U., Watkins, J. L., Barnett, J., Freeman, M., Geenen, J., . . . Fogel, E. L. (2003). Does prophylactic administration of corticosteroid reduce the risk and severity of post-ERCP pancreatitis: a randomized, prospective, multicenter study. Gastrointestinal endoscopy, 58(1), 23-29.

Sugiyono, B. (2003). Program Keselamatan dan Kesehatan Kerja. Semarang: UNDIP.

Umar, M. (2005). Legal Issues in the Management of Nigeria's Production Sharing Contracts from a Study of the Nigerian National Petroleum Corporation's (National Petroleum Management Services') Perspective. Oil, Gas \& Energy Law Journal (OGEL), 3(1).

Wiig, K. M. (1997). Knowledge management: an introduction and perspective. Journal of knowledge Management, 1(1), 6-14. 
